\title{
Analysis of synoptic conditions for tornadic days over western Greece
}

\author{
P. T. Nastos and I. T. Matsangouras \\ Laboratory of Climatology and Atmospheric Environment, Faculty of Geology and Geoenvironment, \\ University of Athens, University Campus, 15784, Athens, Greece \\ Correspondence to: P. T. Nastos (nastos@geol.uoa.gr)
}

Received: 27 February 2014 - Published in Nat. Hazards Earth Syst. Sci. Discuss.: 31 March 2014

Revised: - - Accepted: 12 July 2014 - Published: 10 September 2014

\begin{abstract}
Tornadoes have been reported in Greece during the last few decades and recent studies have given evidence that western Greece is an area vulnerable to tornadoes, waterspouts and funnel clouds In this study, the composite means and anomalies of synoptic conditions for tornadic events (tornadoes, waterspouts and funnel clouds) over western Greece are analyzed and discussed.

The daily composite means of synoptic conditions were based on the National Centers for Environmental PredictionNational Center for Atmospheric Research (NCEP-NCAR) reanalysis data sets, for the period 12 August 1953 to 31 December 2012. The daily composite anomalies were calculated with respect to 30 years of climatological study (19812010) of the synoptic conditions. The analysis was carried out in terms of seasonal and monthly variability of composite means and anomalies of synoptic conditions for specific isobaric levels of 500,700, 850, $925 \mathrm{hPa}$ and the sea level pressure (SLP). In addition, an analysis and discussion about the dynamic lifted index from NCEP-NCAR reanalysis data sets is presented.

The daily composite mean analysis of $500 \mathrm{hPa}$ revealed a trough line across the northern Adriatic Sea and central Italy, associated with a SW upper-air stream over western Greece. The maximum composite anomalies were depicted at the isobaric level of $500 \mathrm{hPa}$ during autumn, spring and summer, against winter when the anomaly appeared at $925 \mathrm{hPa}$ isobaric level. In addition, $48 \%$ of tornado events during the autumn season occurred in pre-frontal weather conditions (cold fronts) and $27 \%$ developed after the passage of the cold front. Furthermore, the main difference in synoptic patterns between tornado and waterspout days along western Greece during the autumn season is the maximum daily composite anomaly over the Gulf of Taranto.
\end{abstract}

\section{Introduction}

Convective weather related to tornadoes (TRs), waterspouts (WSs) and funnel cloud (FC) development could be characterized as one of the most violent of all small-scale natural phenomena. They are associated with extremely high winds, inside and around the tornado's funnel, causing extended damage and in many cases loss of life. Tornadoes and waterspouts have always been fascinating to mankind; they were well known to the ancients (Matsangouras et al., 2014); actually, all of the classical philosophers have provided possible explanations of these extreme events, while during the last 40 years, studies have been motivated in order to understand the mechanisms that produced these phenomena.

As tornadoes occur in many parts of the world (Fujita, 1973), there have been several studies during recent decades that have presented historical records concerning tornadic activity worldwide (e.g., Meaden, 1976; Peterson, 1982, 1992, 1995, 1998; Grazulis, 1993; Tarrant, 1995; Tooming et al., 1995; Reynolds, 1999a, b). Tornadic events and associated phenomena in Ireland have been a continuing feature of the Irish climate for an unknown, but very long, period of time (Tyrrell, 2001). Setvák et al. (2003), presented that the oldest records of tornado occurrence within the Czech Republic can be found in chronicles from the first half of the 12th century and several other cases of possible tornadoes and waterspouts can be found in chronicles from the 12th and 13th centuries. Moreover Brázdil et al. (2012) showed that the tornado history of the Czech lands consisted of a total of 264 tornado days and more than 307 tornadoes were documented within 1119-2010. According to the data of the Lithuanian Hydrometeorological Service, there were 23 tornadoes recorded in Lithuania in the period of 1950-2002 
(Marcinoniene, 2003). Nastos and Matsangouras (2010) presented that during the 20th century, more than 33 whirlwind phenomena caused 4 fatalities, injuries to more than 40 people, as well as numerous damage on human constructions and cultivations were reported. Gayà et al. (2011) constructed a database containing 97 tornadoes and 62 waterspouts that affected Catalonia over the period 1950-2009. Rahuala et al. (2012), described the process of collecting and evaluating tornado reports, thus 298 Finnish tornado cases composed the climatology: 129 from the historical data set and 169 from the recent data set. Similar, Matsangouras et al. (2014) presented a tornado climatology based on historical data sets (1709-1999) and recent data sets (2000-2012), thus more than 612 Greek tornadic events were recorded: 171 tornadoes, 374 waterspouts and 67 funnel clouds, within the period 1709-2012.

In spite of these historical publications, several researchers have presented/analyzed tornado occurrences and climatology for many European countries describing the spatiotemporal distribution of these tornadic phenomena (e.g. Dessens, 1984; Dessens and Snow, 1987; Paul, 1999; Gayà et al., 2000). Dotzek (2001) suggested a conservative estimate of tornadic activity in Germany, a number of four to seven tornadoes per year and a recurrence density of about 0.1 to $0.2 \times 10^{-4}$ events year ${ }^{-1} \mathrm{~km}^{-2}$. Dotzek (2003) showed a total of $329 \pm 12$ tornadoes over land and water per year based on observations, and more than twice as many cases $(697 \pm 36)$ for an estimate of the expected true climatological number over Europe. Holzer (2001) based on a database consisted of 89 tornadoes suggested that the overall average for Austria is $0.3 \times 10^{-4}$ tornadoes per year ${ }^{-1} \mathrm{~km}^{-2}$.

Bertato et al. (2003) presented an interesting case of tornado on the Friuli plain (Northeastern Italy) on 26 March 2001 while radar and mesonetwork data revealed the presence of a supercell mesocyclone. Regarding Italy, numerous tornadoes have traversed southern Apulia (Italy) in the course of the last 5 centuries, causing severe damage and a significant loss of life, thus, 24 small towns and villages of southern Apulia suffered on at least one occasion the disastrous effects of being hit by a tornado (Gianfreda et al., 2005). Giaiotti et al. (2007) presented that tornadoes and waterspouts over Italy are more frequent in late summer and autumn than in the other seasons. Keul et al. (2009) showed the geographical distribution and frequency of 110 waterspouts, for the years 2002-2006, over the central eastern Mediterranean. Sioutas (2011) based on 10 years of data (2000-2009), suggested a mean annual number of 1.1 tornadoes per unit area of $10^{4} \mathrm{~km}^{2}$ for Greece. Moreover, Matsangouras et al. (2014) based on 13 years of data (20002012) revealed that Greece is experienced an annual mean of more than 42.15 tornadic events, while the maximum tornado frequency is evident over NW Peloponnese (western Greece).

In Greece, significant research has been carried out during the last decade, including tornado and waterspout overviews and climatology (Sioutas, 2003; Nastos and Matsangouras, 2010; Matsangouras et al., 2011a, 2014) and waterspout occurrences and forecasting (Sioutas and Keul, 2007; Keul et al., 2009). In addition to these climatological studies, reports and analyses of some important tornado and waterspout case studies have been performed (Matsangouras and Nastos, 2010; Matsangouras et al., 2010, 2011b, 2012; Nastos and Matsangouras, 2012).

The knowledge of spatiotemporal distribution of tornadic events along with the awareness of the synoptic conditions that favour tornadic storms could be characterized as the first stage to set up an effective tornado warning process. This is of high concern in order to help local forecasters to determine the synoptic conditions, which are associated with the development of tornadic events across the different largescale terrain features of western Greece. Thus, the objective of this study is on one hand to compile a 60-year climatology (1953-2012) of tornadoes/waterspouts across western Greece in order to examine the mean synoptic patterns related to these phenomena, and on the other hand to interpret the daily composite anomalies of the synoptic conditions with respect to specific isobaric levels. Recognized synoptic weather patterns could be considered by forecasters to detect the potential of tornadic occurrence and a detailed nowcasting procedure could be set up for that day, in contrast to radar severe storm signature or tornado spotter reports that are used in short time.

Several studies during recent years have presented synoptic environmental conditions that produce tornadic development over United States, Finland and Greece. Rauhala and Schultz (2009), based on a climatology containing 253 tornadoes and 184 tornado days in Finland (1948-2007), analyzed and characterized the environment of each tornado day in four synoptic types. These four patterns classify $73 \%$ (22) of the 30 significant-tornado days in Finland since 1948. In addition, a comparison between those four patterns and those patterns observed in the United States (Miller, 1972), revealed that most US patterns showed a much clearer wind veering with height than patterns over Finland. Tornado cases of Finland categorized in pattern A and C, occurred in an upper-level south-westerly flow in front of an approaching $500 \mathrm{hPa}$ trough (Rauhala and Schultz, 2009). Similarly, a south-westerly flow of an approaching trough was evident on synoptic analysis of a tornadic event in northern Greece (Matsangouras et al., 2011b). Sioutas (2011) presented that a short wave trough is found as the most relevant synoptic circulation pattern for tornadic activity over Greece. Moreover, the composite mean of synoptic conditions at $500 \mathrm{hPa}$ isobaric level for tornadic days during autumn over NW Greece revealed a long wave trough from NW Italy to Sicily, causing a SW upper air flow over the northern Ionian Sea. Matsangouras et al. (2014) showed the composite daily synoptic conditions at $500 \mathrm{hPa}$ isobaric level and sea level pressure (SLP) for specific regions favourable for tornadogenesis (NW Ionian Sea, NW Peloponnese and southern Aegean 
Sea). In all synoptic patterns, $\mathrm{SW}$ air flow at $500 \mathrm{hPa}$ isobaric level was the dominant feature associated with a long wave trough.

The analysis of composite means and anomalies of synoptic conditions was carried out with respect to the tornadic type: (a) tornadoes and (b) waterspouts, as it is commonly accepted that different potential processes guide these phenomena. Tornado is known as a rapidly rotating column of air that occurs in association to a cumuliform cloud. The most intense type of tornado arises within a special type of this cloud, known as a super-cell thunderstorm. Most of what is known in fluid dynamics about tornadoes comes from laboratory and numerical model simulations of the super-cell thunderstorm. It is modelled as a circular updraft fed by air possessing angular momentum with respect to the updraft centre axis experiments, simulating vortices that share similarities with what can be observed in a tornado in nature (e.g., Rotunno, 1977, 1978, 1979, 1980, 1984; Fiedler and Rotunno, 1986; Wilson and Rotunno, 1986; Klemp, 1987; Howells et al., 1988; Fiedler, 2009; Rottuno, 2013). Fundamental processes of waterspout formation and detailed structural analyses have been examined by Golden (1973, 1974a, b, 1977), describing the five stages of waterspout: (1) the dark spot, (2) the spiral pattern, (3) the spray ring, (4) the mature waterspout and 5) the decay stage. Golden (1974b) introduced waterspout association with energy and angular momentum fluxes among five scales of circulation: (1) the funnel scale (3-150 m), (b) the spiral scale (150-1000 m), (c) the individual cumulus-cloud scale (from less than 2 to $10 \mathrm{~km}$ ), (4) the cumulus cloud-line scale (10-200 km) and (5) the synoptic scale.

The structure of the paper consists of Data and methodology in Sect. 2, Results and discussion in Sect. 3 and finally Conclusions are presented in Sect. 4.

\section{Data and methodology}

The Laboratory of Climatology and Atmospheric Environment, University of Athens (LACAE, http://lacae.geol.uoa. gr) has undertaken a systematic effort in recording tornadoes, waterspouts, and funnel clouds in Greece, since 2007. LACAE developed in 2009 an open-ended online tornado report database web system (http://tornado.geol.uoa.gr), contributing to the compilation of a climatology of these extreme weather events. LACAE is in close collaboration with European Severe Storm Laboratory (ESSL) and submit in regular basis reports to European Severe Weather Database (ESWD).

The main goal of the Greek tornado report system is to collect, verify and provide detailed and quality-controlled information of tornadic activity over Greece, using a web-based geographical user interface application and homogeneous data reports. Regarding the verification process of this system, the submitted tornado report, after passing a plausibility check by a quality control manager based on confirmation from several sources (newspaper, Hellenic National Meteorological Service (HNMS), internet, TV, etc.), is stored in the database. Furthermore, the attached media files, and the liability of the user are also taken into consideration during the verification process. A detailed flowchart of LACAE's verification project is presented by Matsangouras et al. (2014).

In this study, the authors have used a tornadic climatology, containing 79 tornadoes and 156 waterspouts in 59 and 105 days respectively, in western Greece (1953-2012). The daily composite mean and anomaly of synoptic days for tornadoes and waterspouts over western Greece were analyzed and discussed based on the aforementioned climatology. Funnel clouds that were spotted over the water body of the Ionian Sea were characterized as waterspouts. The atmospheric environment of each tornado day was identified by data sets acquired from the National Centers for Environmental Prediction-National Center for Atmospheric Research (NCEP-NCAR) reanalyses (Kalnay et al., 1996), for the period 12 August 1953 to 31 December 2012. The daily composite anomalies of the synoptic conditions were calculated with respect to 30 years climatology (19812010).

The analysis of composite means and anomalies of synoptic conditions was carried out in terms of seasonal and monthly variability for specific isobaric levels of 500, 700, $850,925 \mathrm{hPa}$ and the sea level pressure (SLP). In addition, an analysis and discussion is presented based on the dynamic lifted index (LI) from NCEP-NCAR reanalysis data sets.

\section{Results and discussion}

\subsection{Spatiotemporal variability of tornadoes and waterspouts over western Greece}

Our analysis concerns the period 1953-2012, as the first event was recorded on 12 August 1953 at Zante Island (central Ionian Sea, Fig. 1), and the latest event on 27 December 2012 at Corfu Island (NW Greece, Fig. 1). A total of 235 events have been recorded and catalogued in 165 days, as there were several days with multiple events. During this period (1953-2012), the 235 recorded events consisted of 79 tornadoes, 135 waterspouts and 21 funnel clouds.

Figure 1a shows that tornadoes are more prominent over specific sub geographical regions along western Greece. Moreover, it is evident that tornadoes maximum appearance is over western Greece, as maximum frequency appears over NW Peloponnese, central and southern parts of Corfu Island, Zante Island and around the Messinian Gulf of southern Peloponnese. Over those geographic areas it is noticed that the atmosphere-land synergies provide unstable weather conditions, which are favourable to tornadogenesis, especially during autumn (the dominant season) when sea surface temperature is getting its maximum over the Ionian Sea. Thus, several cold fronts develop significant 
a)
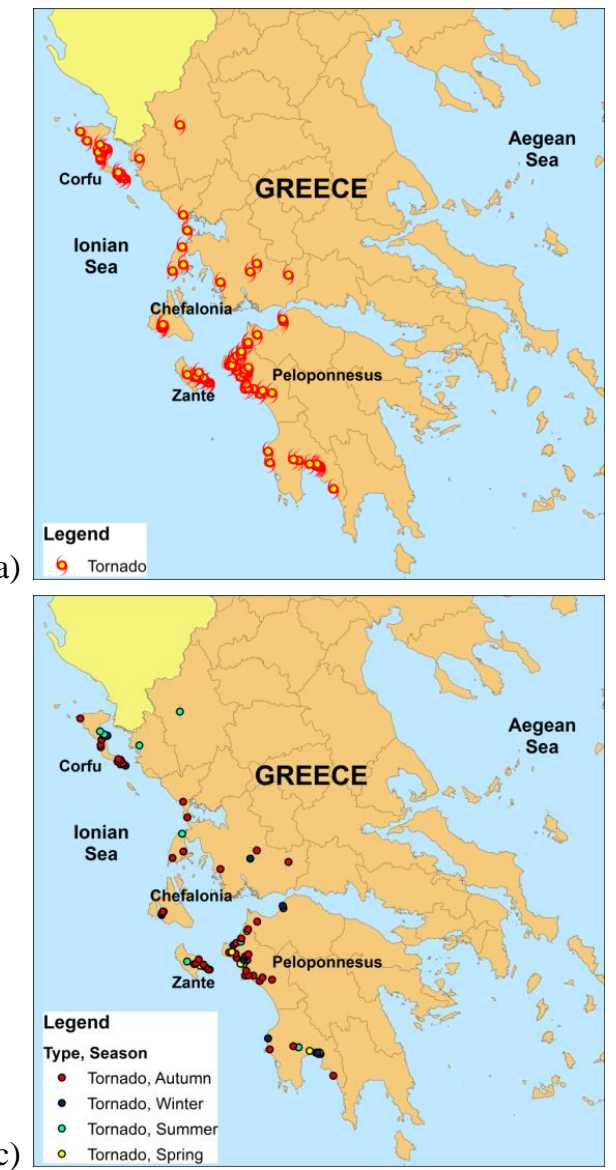

b)
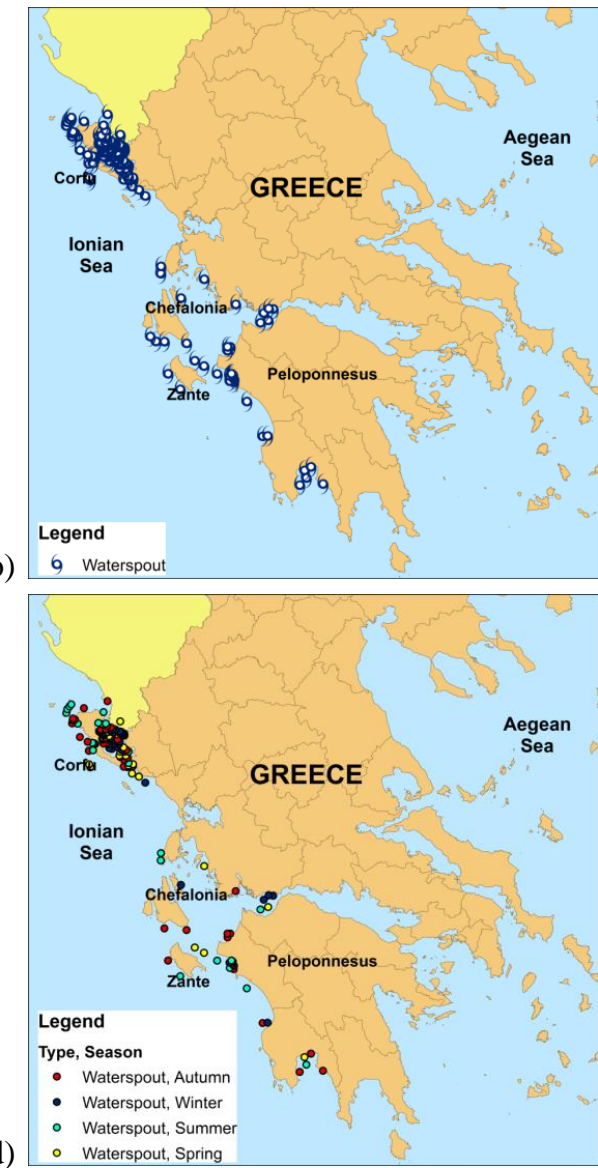

Figure 1. Annual spatial distribution of tornadoes (a) and waterspouts (b), along with the seasonal spatial distribution of tornadoes (c) and waterspouts (d) over Western Greece for the period 12 August 1953-31 December 2012.

unstable conditions. Significant convective weather appears over western Greece during autumn, as more than 7 flashes per $\mathrm{km}^{2}$ are calculated based on Lightning Detection Network of HNMS (Nastos et al., 2014).

Similarly to the spatial distribution tornadoes, waterspouts can occur anywhere over the Ionian Sea, but they appear more frequently around Corfu Island (Fig. 1b). Fifty-six percent of waterspout occurrence in western Greece concerns waterspouts located between the east coasts of Corfu and west coasts of the Greek mainland. Additionally, waterspouts are favoured along the coasts of NW Peloponnese, over the Messinian Gulf and around Zante's and Cefalonia's coasts. Although the majority of waterspout events have been reported close to the coasts, there are several cases of waterspouts in open seas, reported by sailors. Several waterspouts have come offshore causing significant damage (these cases have been characterized as tornadoes). An example of such a case is the waterspout that came offshore in Vlychos Bay, in the marine of Lefkada Island, causing significant damage to several moored boats and one fatality, on 20 September 2011.

Matsangouras et al. (2011a), studying the occurrence of tornadic events within the period 1709-2010, suggested that the spatial density over the northern Ionian area and NW Peloponnese equals to 0.36 and $0.09 \times 10^{-4}$ events year ${ }^{-1} \mathrm{~km}^{-2}$, respectively. Taking into consideration the period 2001-2010, Nastos and Matsangouras (2012) suggested that the density over the northern Ionian Sea area increases rapidly to $9.42 \times 10^{-4}$ events year ${ }^{-1} \mathrm{~km}^{-2}$, that is $1.16 \times 10^{-4}$ TR events year ${ }^{-1} \mathrm{~km}^{-2}$ and $7.56 \times 10^{-4}$ WS events year ${ }^{-1} \mathrm{~km}^{-2}$. Moreover, studying the last 13 years (2000-2012), these values over the northern Ionian Sea could be considered constants, as they only slightly changed to $9.52,1.03$ and $7.73 \times 10^{-4}$ events year ${ }^{-1} \mathrm{~km}^{-2}$, respectively (Matsangouras et al., 2014). During the same studied period (2000-2012), the TR and WS density over NW Peloponnese appears to be 1.38 and $1.16 \times 10^{-4}$ events year ${ }^{-1} \mathrm{~km}^{-2}$, respectively, against decreased densities, over the southern parts of Peloponnese, that is 0.7 and $0.63 \times 10^{-4}$ events year ${ }^{-1} \mathrm{~km}^{-2}$, respectively (Matsangouras et al., 2014).

The mean annual tornadic events frequency, based on 300 years of climatology (1709-2010), is 0.31 for the northern Ionian Sea, 0.23 for NW Peloponnese and 0.08 over the southern parts of Peloponnese (Matsangouras et al., 2011a). Furthermore, the mean annual tornadic activity over western 

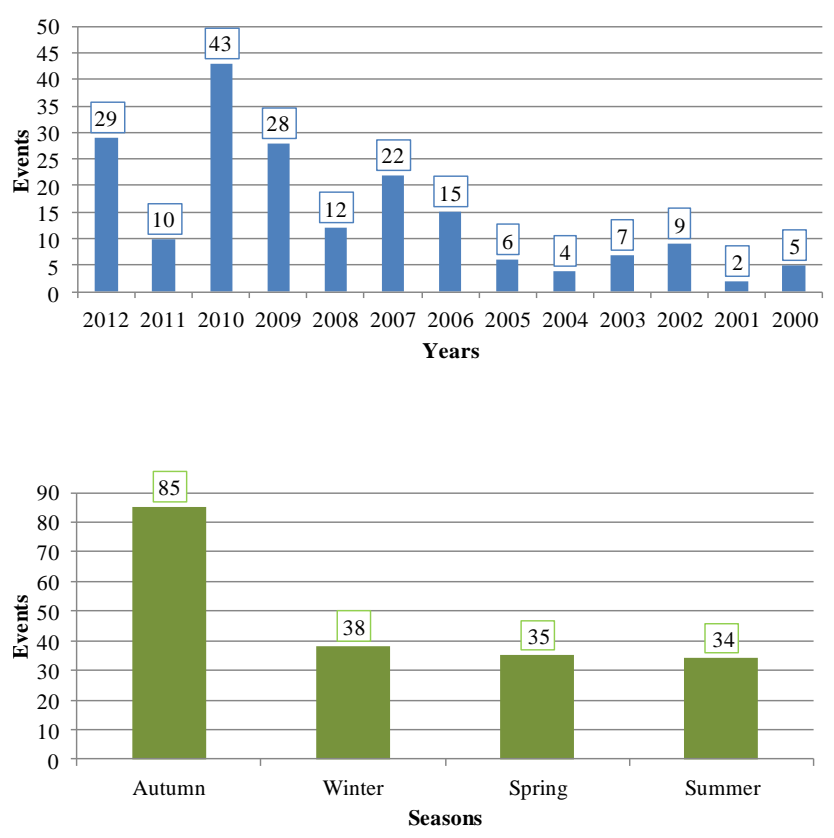

Figure 2. Annual (upper graph) and seasonal (lower graph) distribution of tornadic events over western Greece for 2000-2012.

Greece during the last 13 years (2000-2012) has been assessed to be 19.09 events (Matsangouras et al., 2014). Matsangouras et al. (2014) estimated that the mean annual tornadic activity over the northern Ionian Sea corresponds to 8.53 events (6.92 WS and $0.92 \mathrm{TR}$ ), 5.54 events ( $2.38 \mathrm{WS}$ and $2.85 \mathrm{TR})$ for NW Peloponnese, and 1.54 events ( 0.77 WS and 0.85 TR) over southern parts of Peloponnese. Autumn favours the development of tornadic events, as more than $45 \%$ of these events have been recorded during autumn, followed by winter $(20 \%)$ and summer $(16 \%)$.

Tornadoes are more frequent during autumn over central and the southern parts of Corfu Island. Similarly, tornadoes are dominant during autumn over NW Peloponnese and Zante Island, in contrast to the Messinian Gulf area, where tornadoes are equally distributed within all seasons (Fig. 1c). On the other hand, waterspout frequency exhibits a maximum during autumn over the northern Ionian Sea, followed by less frequency of occurrence during summer and winter (Fig. 1d). Waterspouts along the rest western Greece (apart from the northern Ionian Sea) occur during all seasons. Figure 2 illustrates the annual and seasonal distribution of tornadic events over western Greece for 2000-2012. This seasonal pattern is in agreement with the aforementioned seasonal variability of tornado events and with the findings derived by recent studies (Matsangouras et al., 2011, 2014; Sioutas, 2011; Nastos and Matsangouras, 2012).

It has been found that tornadoes and waterspouts occur during all months over western Greece (not shown). The monthly variability of events within the period 1953-2012, depicts a maximum during November, followed by Octo-

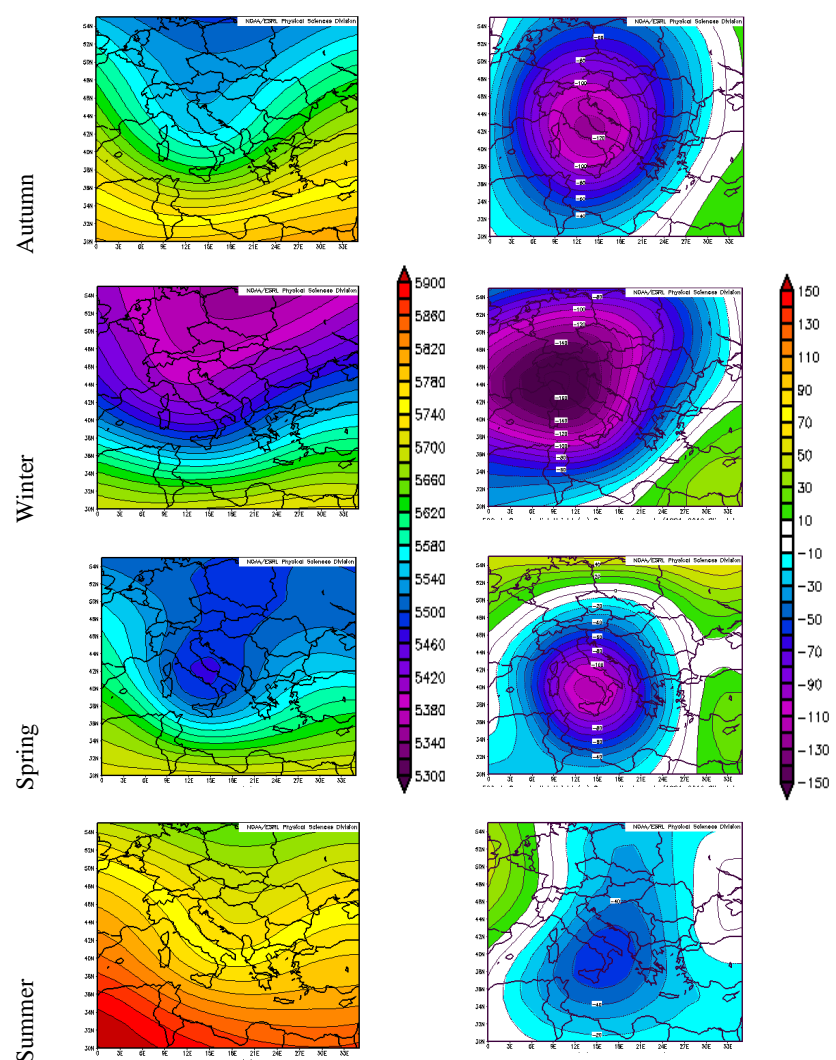

Figure 3. Seasonal daily composite means (left column) and anomalies (right column) of geopotential heights at $500 \mathrm{hPa}$ isobaric level for tornado days over western Greece for the period $12 \mathrm{Au}$ gust 1953-31 December 2012.

ber, September and December. November is the month with the highest TR frequency, followed by October. Similarly, WSs are frequent during November, followed by October, September. This monthly TR distribution over Greece is more different than the respective distribution over central European countries. The maximum monthly TR frequency appears during the warm season (from June to August) over the continental region of central Europe, as already stated by Wegener (1917), Dotzek (2001) and Rahuala et al. (2012).

\subsection{Synoptic conditions associated with tornado development over western Greece}

The synoptic-scale conditions associated with the development of tornadoes, in terms of seasonal and monthly composite analyses, are discussed in this section. Figure 3 shows the daily composite means (left column) and daily composite anomalies (right column) of geopotential heights (m) at $500 \mathrm{hPa}$ isobaric level for TR days during autumn (the most active season), winter, spring and summer. Further, Fig. 4 shows the daily composite means (left column) and daily composite anomalies (right column) of SLP for the aforementioned seasonal periods. The daily composite means (left 

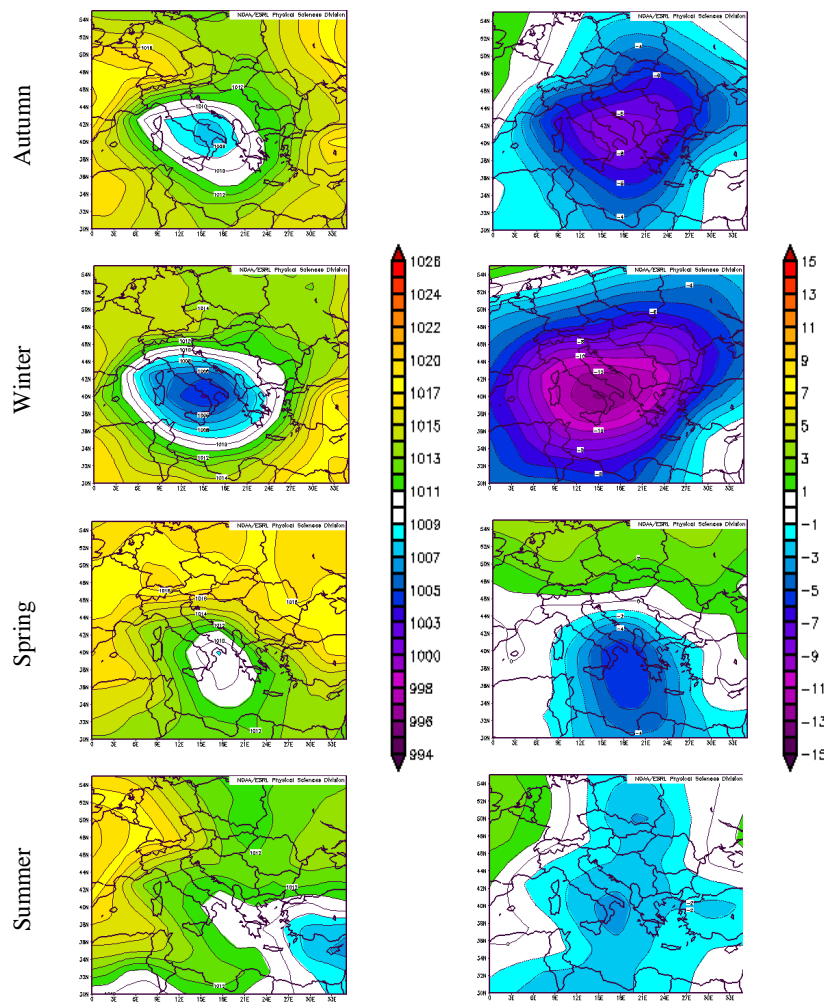

Figure 4. Seasonal daily composite means (left column) and anomalies (right column) of sea level pressure for tornado days over western Greece for the period 12 August 1953-31 December 2012.

column) and anomalies (right column) of LI for the aforementioned seasonal periods are illustrated on Fig. 5.

Over western Greece, the daily composite mean synoptic conditions at $500 \mathrm{hPa}$ level for TR days, during autumn, are characterized by a broad trough along central and southern Italy, associated with a SW upper-air stream over the study area (Fig. 3). At $700 \mathrm{hPa}$ level (not shown) a long trough is oriented from the northern Adriatic Sea to Sicily in contrast to the lower pressure levels of 850 and $925 \mathrm{hPa}$ (not shown), where a closed cyclonic circulation is evident over central Italy. The centre of the cyclonic circulation at the surface $(1008 \mathrm{hPa})$ is located over central Italy and the Gulf of Taranto (Fig. 3). The daily composite anomaly of geopotential heights (m) at $500 \mathrm{hPa}$ level appears to be more than $-120 \mathrm{~m}$ centered over the central Italy (Fig. 4). The maximum composite anomaly (not shown) at 700-850 and $925 \mathrm{hPa}$ lower isobaric levels of the troposphere appears southeasterly, covering a more broad area over the southern Adriatic Sea, with values equal to $-90,-70$ and $-50 \mathrm{~m}$, respectively. Over central Italy, the daily composite anomaly of SLP during TR days is assessed to be $-8 \mathrm{hPa}$ (Fig. 4). Long-term means (clino) during autumn(not shown), based on NCEP-NCAR reanalysis 1981-2010 period, at 500 and $700 \mathrm{hPa}$ isobaric levels (not shown), and revealed a zonal flow over southern Europe. At lower isobaric levels (850-
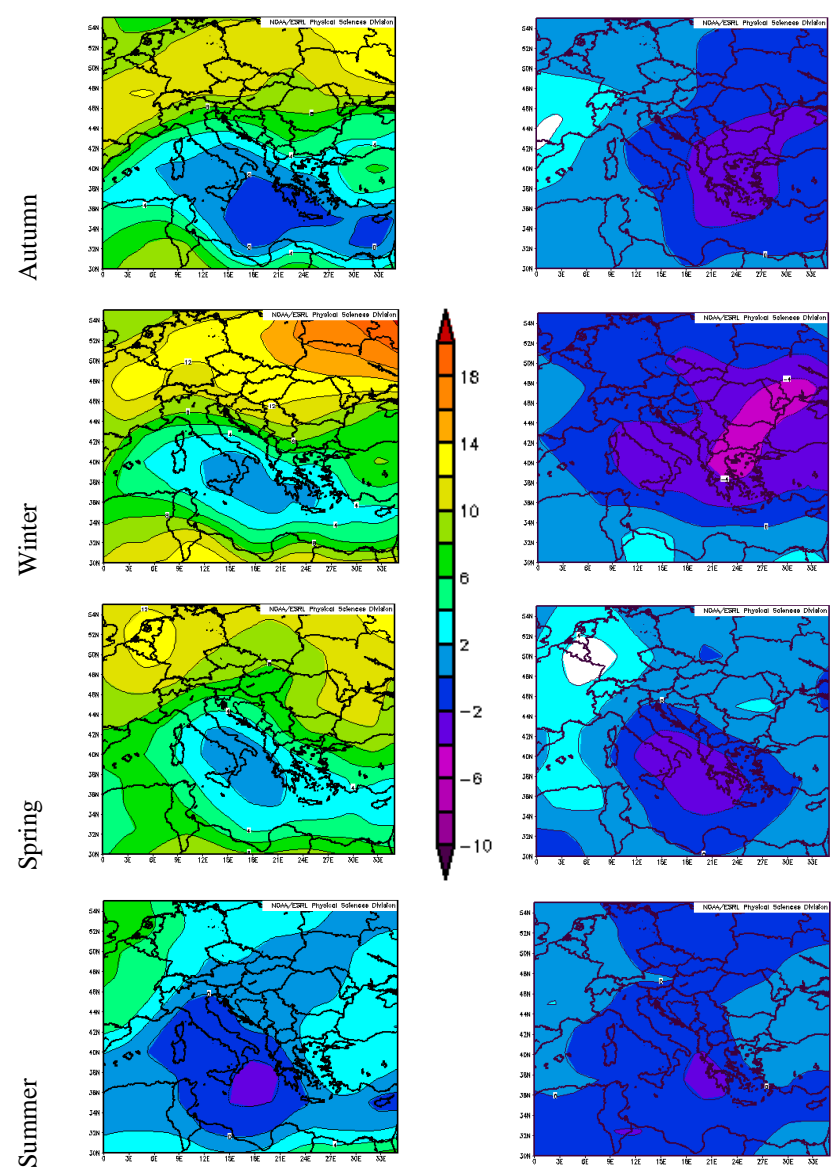

Figure 5. Seasonal daily composite means (left column) and anomalies (right column) of LI for tornado days over western Greece for the period 12 August 1953-31 December2012.

$925 \mathrm{hPa}$ ), a minor trough is located over Corsica (not shown), while a shallow cyclonic circulation is evident over central the Mediterranean Sea (Corsica-Italy) against to the eastern Mediterranean Sea, where high geopotential heights over the Balkans are combined to a shallow trough over east Mediterranean Sea, establishing an E-SE air flow over western Greece and Ionian Sea.

Daily composite means of synoptic conditions at 500 and $700 \mathrm{hPa}$ isobaric levels (not shown) for TR days during winter, are characterized by a broad trough along north Italy and over the sea body area between Corsica and southern Italy, associated with a SW upper-air stream over western Greece (Fig. 3). A broad cyclonic circulation is evident from eastern Corsica to the central Adriatic Sea at $700 \mathrm{hPa}$ level (not shown) in contrast to SLP at $925 \mathrm{hPa}$ level (not shown), where the cyclonic circulation is limited over central Italy, causing a S-SW air flow pattern over western Greece. The daily composite anomaly at $500 \mathrm{hPa}$ isobaric level reveals values greater than $-160 \mathrm{~m}$ over northern Italy and a range from -40 and $-90 \mathrm{~m}$ over western Greece. The aforementioned maximum anomaly of geopotential heights at $500 \mathrm{hPa}$ 
level is relocated from NW Italy to central Italy and over the Gulf of Taranto, as we are studying the lower isobaric levels of troposphere (700-850-925 hPa; not shown) and SLP (Fig. 4). Based on NCEP-NCAR long-term climatology (not shown) of geopotential heights at 500 and $700 \mathrm{hPa}$ levels, a long trough is located over the central Adriatic Sea. At $925 \mathrm{hPa}$ level (not shown) and SLP, a broad shallow low centre appears between Corsica and Italy.

During the spring season, the daily composite means reveal a closed cyclonic circulation from middle $(500 \mathrm{hPa})$ to lower isobaric levels of troposphere (Fig. 3). As far as SLP is concerned, the low centre $(1009 \mathrm{hPa})$ is located over central Italy, around the Gulf of Taranto. These synoptic conditions implied a SW air flow over the southern Ionian Sea and a S-SW air flow pattern over the rest parts of western Greece. The maximum daily composite anomaly at $500 \mathrm{hPa}$ isobaric level $(-110 \mathrm{~m})$ appears at the north of Sicily (Fig. 3) and it is relocated smoothly over SE Sicily at lower isobaric levels of 700-850 and $925 \mathrm{hPa}$ (not shown). At SLP, a broad daily composite anomaly is found between Italy and western Greece (Fig. 4). Clino synoptic conditions at 500 and $700 \mathrm{hPa}$ levels (not shown) present a trough line westwards of Italy and a shallow ridge line over southern Greece. Regarding the $925 \mathrm{hPa}$ level and the SLP (not shown), the cyclonic circulation is closed between north Sicily and the Gulf of Genoa.

Tornadoes during summer days over northern parts of Greece are associated with convective weather conditions (unstable atmospheric environment), mainly caused by lower atmospheric heating procedure during summer hot days. Tornadoes over the western parts of Greece are related to the aforementioned heating-instability procedure, and they are also enhanced by a thermo-dynamically unstable environment to the west of Greece. At $500 \mathrm{hPa}$ level, a long trough appears over eastern Europe tilting to the southern parts of Italy, causing a western upper air stream (Fig. 3). This trough line at $700 \mathrm{hPa}$ level (not shown) could be described as two separate trough lines: the northern trough line, located along eastern Europe and the southern trough line along the central Adriatic Sea and Corsica. At 850 and $925 \mathrm{hPa}$ isobaric levels (not shown), the northern part of the aforementioned trough line is tilted, causing a meridian air flow pattern. The daily composite mean of SLP reveals a shallow cyclonic circulation over the Ionian Sea, implying a light S-SW surface air stream over the western Greek mainland (Fig. 4). Maximum daily composite anomaly of geopotential heights at $500 \mathrm{hPa}$ during summer days, is identified over the central and southern parts of Italy with values lower than -60 and $-40 \mathrm{hPam}$, over western Greece (Fig. 3). The composite anomalies of geopotential heights over western Greece vary from -40 to $-20 \mathrm{hPam}$ at lower isobaric levels of 700,850 and $925 \mathrm{hPa}$ (not shown). Regarding SLP the anomaly is centred over the Gulf of Taranto with values from -4 to $-3 \mathrm{hPa}$ (Fig. 4). SLP clino depicts a combination of high pressures over central Europe with a low pressure system over the Middle East, causing a NE surface air stream. In the upper air clino daily composite maps (500 and $700 \mathrm{hPa}$ levels; not shown), a ridge line is evident along Algeria, western Mediterranean Sea, implying a NW upper air stream over western Greece. Studying the isobaric levels of $850 \mathrm{hPa}$ (not shown), a minor trough is located along north Italy-Corsica, negatively tilted and oriented south of the Gulf of Genoa at $925 \mathrm{hPa}$ level (not shown). At both these levels, the upper air stream over the area of interest is from north directions implying a cold dry air mass advection.

In the process, the synoptic-scale conditions associated with TR development over western Greece, based on monthly composite analyses, are presented. Daily composite means of SLP (not shown) during cold months (December and January) reveal a closed cyclonic circulation over the northern Ionian Sea and the Gulf of Taranto, with isobar lines of 1009 and $996 \mathrm{hPa}$, respectively. A south-southwest surface air stream is established over western Greece as a low pressure system appears over Corsica (1005 hPa) during TR days in February. During March and April, a broad closed low pressure system (1011 and $1010 \mathrm{hPa}$, respectively) is present over the Ionian Sea and southern Italy, in contrast to a shallow cyclonic circulation over the Gulf of Genova during TR days in May. During the months of the hot season (June, July and August), a shallow, unclosed cyclonic circulation is evident over the northern Ionian Sea and the Gulf of Taranto, as high pressure system over central Europe is combined to low pressure system over east Mediterranean Sea. During the autumn months (September, October and November) a closed cyclonic circulation is identified over central Italy and is relocated further SE from the Gulf of Taranto with a steady $1009 \mathrm{hPa}$ pressure centre, implying a surface wind from south directions over the northern Ionian Sea and S-SW winds over the south Ionian Sea and Peloponnese.

As described in Sect. 3.1, TR intra annual variability revealed that during November and October tornadoes are more frequent. During TR days in November, a long wave trough at $500 \mathrm{hPa}$ level is oriented from NE Italy to the north coasts of Africa, implying a SW upper air stream. This trough line persists also at $700 \mathrm{hPa}$ level in contrast to 850 and $925 \mathrm{hPa}$, where a closed cyclonic circulation is located over central Italy. Concerning SLP, a low pressure centre appears over central Italy with a mean pressure of $1004 \mathrm{hPa}$. During TR days in October, at $500 \mathrm{hPa}$ level, a long trough is identified along the northern Balkans and eastern coasts of Italy and a second one between south France and north of Corsica. At $700 \mathrm{hPa}$ level, the trough is along the Gulf of Taranto and eastern Sicily. Closed cyclonic circulation is observed over central Italy and south Adriatic Sea, indicating a W-SW air flow stream. At SLP, the low pressure centre $(1008 \mathrm{hPa})$ is located over the Gulf of Taranto. The daily composite anomaly of geopotential heights at $500 \mathrm{hPa}$ level during November TR days depicts a maximum $(-140 \mathrm{~m})$ over central Italy, which is relocated over the central Adriatic Sea as we descend to the lower levels of troposphere. On the contrary, in October, the daily composite anomaly appears 

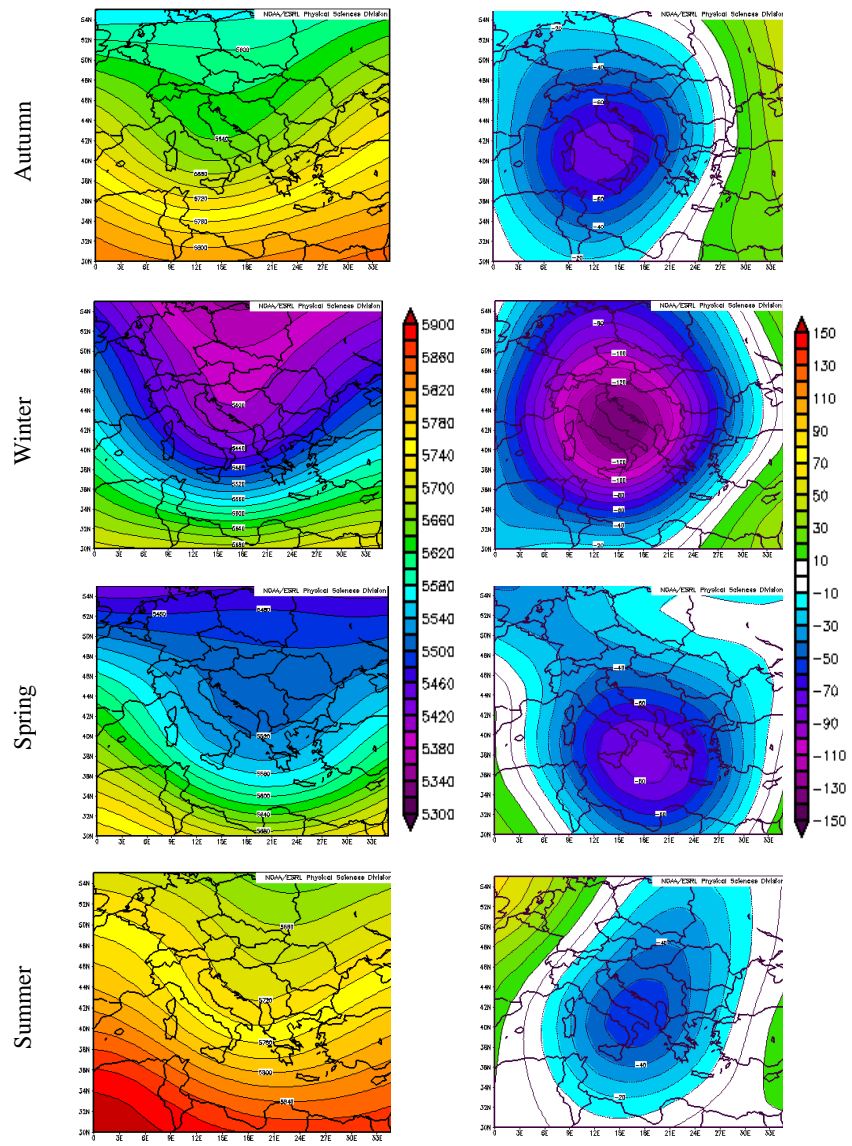

Figure 6. Seasonal daily composite means (left column) and anomalies (right column) of geopotential heights at $500 \mathrm{hPa}$ isobaric level for waterspout days over western Greece for the period $12 \mathrm{Au}$ gust 1953-31 December 2012.

over the southern Adriatic Sea and is relocated further SE at lower isobaric levels. Moreover, the anomalies of geopotential heights appearing in October TR days are almost $50 \%$ weaker $(-80 \mathrm{~m}$ at $500 \mathrm{hPa}$ level) at all barometric levels of lower troposphere, against the respective anomalies appearing in November. The daily composite anomaly of SLP during November is higher over NW Greece, compared to the anomaly of SLP in October.

\subsection{Synoptic conditions associated with waterspout development over western Greece}

Synoptic-scale conditions associated with the development of waterspouts, based on seasonal and monthly composite analyses, are discussed in this section. Figure 6 depicts the daily composite means (left column) and anomalies (right column) of the geopotential heights (m) at $500 \mathrm{hPa}$ for WS days during autumn (the most active season), winter, spring and summer. Besides, Fig. 7 shows the daily composite means (left column) and anomalies (right column) of SLP for the aforementioned seasonal periods. The daily composite

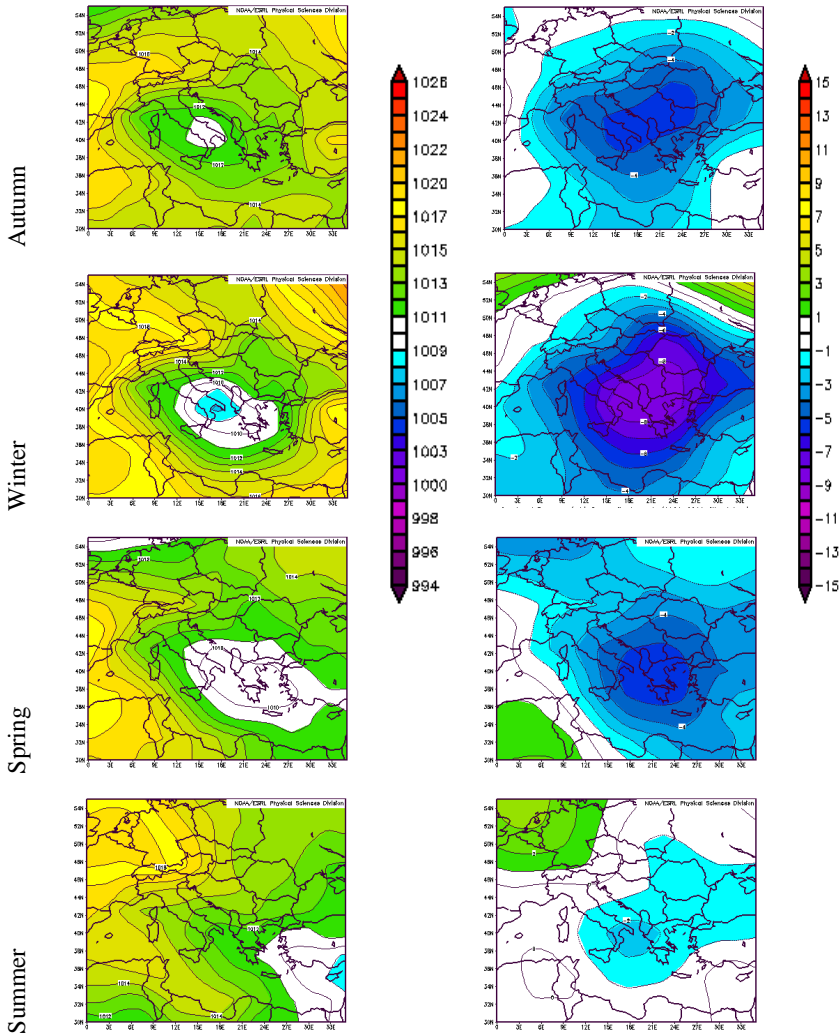

Figure 7. Seasonal daily composite means (left column) and anomalies (right column) of sea level pressure for waterspout days over western Greece for the period 12 August 1953-31 December 2012 .

means (left column) and anomalies (right column) of LI for the aforementioned seasonal periods are illustrated on Fig. 8.

Over the western Greece, the daily composite mean synoptic conditions at $500 \mathrm{hPa}$ level for autumn WS days, are characterized by a broad trough along central and southern Italy, associated with a SW upper-air stream over western Greece (Fig. 6). At $700 \mathrm{hPa}$ level (not shown), a trough is oriented from the north Adriatic Sea to Sicily in contrast to the lower isobaric levels of 850 and $925 \mathrm{hPa}$ (not shown), where a closed cyclonic circulation is identified over central Italy and the central Adriatic Sea. Regarding SLP, (Fig. 7), a closed cyclonic circulation appears over central Italy $(1011 \mathrm{hPa})$.

During winter WS days, the daily composite mean of synoptic conditions at the tropospheric levels of $500 \mathrm{hPa}$ (Fig. 6) and $700 \mathrm{hPa}$ (not shown), are characterised by a through along the Adriatic Sea and southern parts of Italy, implying a SW-W upper air stream. At lower levels of troposphere (850 and $925 \mathrm{hPa}$, not shown), a closed cyclonic circulation is observed over the southern Adriatic Sea and over the Gulf of Taranto, respectively. A closed low pressure centre $(1008 \mathrm{hPa})$ is located over the Gulf of Taranto with respect to the sea level pressure (Fig. 7). 

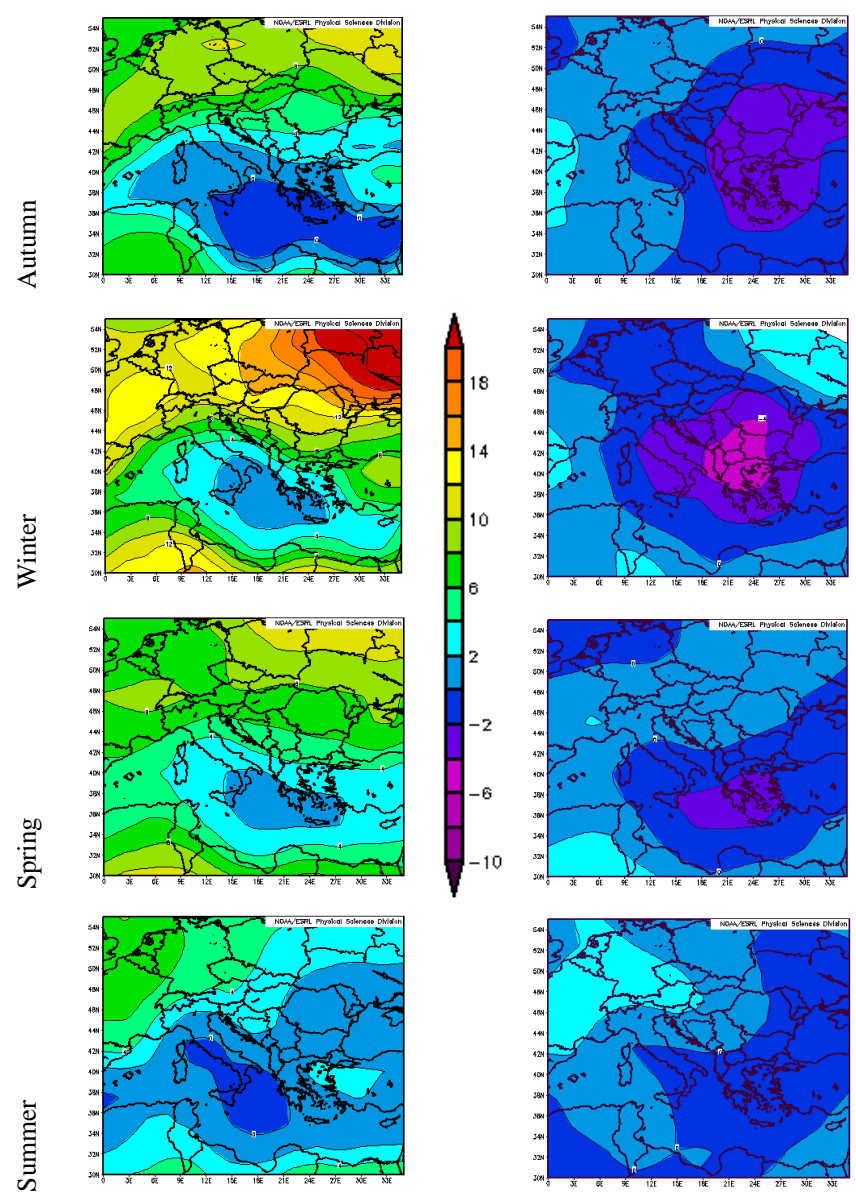

Figure 8. Seasonal daily composite means (left column) and anomalies (right column) of LI for waterspout days over western Greece for the period 12 August 1953-31 December 2012.

Analyzing the isobaric levels of middle troposphere (500 and $700 \mathrm{hPa}$ ) for spring WS days, it is found that a trough appears over the Ionian Sea (between Italy and Greece), suggesting a SW upper air stream over western Greece (Fig. 4). Taking into consideration the isobaric levels of 925 and $850 \mathrm{hPa}$ (not shown), a closed cyclonic circulation is evident over NW Greece. The daily composite mean of SLP for spring WS days, is identified by an extended low pressure system $(1010 \mathrm{hPa})$ from central Italy to the eastern parts of the Aegean Sea (Fig. 7).

During summer WS days, the daily composite means of geopotential heights at $500 \mathrm{hPa}$ (Fig. 6) and $700 \mathrm{hPa}$ (not shown) isobaric levels reveal a W-SW upper air stream over western Greece as a trough is established along the Ionian Sea. The combination of high geopotential heights over central Europe and low geopotential heights over the eastern Mediterranean causes a NW upper air stream at 850 and $925 \mathrm{hPa}$ (not shown). The same combination is also evident at SLP, implying a NW surface stream over western Greece (Fig. 7).
The maximum daily anomalies of geopotential heights at $500 \mathrm{hPa}$ level, for WS days during cold seasons (autumn and winter) (Fig. 6) appear over central Italy ( -70 and $-130 \mathrm{~m}$, respectively). During spring WS days, the daily composite anomaly of geopotential heights at $500 \mathrm{hPa}$ level is higher $(-80 \mathrm{~m})$ over the southern parts of Italy and Ionian Sea, in contrast to lower summer anomalies $(-50 \mathrm{~m})$ appearing over central Italy, the northern Ionian Sea and southern parts of the Adriatic Sea (Fig. 6). The daily composite anomaly of SLP during autumn WS days is maximum over central Italy and southern parts of the Balkans $(-5 \mathrm{hPa})$. During winter WS days, the daily composite anomaly of SLP appears to be higher $(-8 \mathrm{hPa})$ over northern Greece and the Gulf of Taranto, against weaker anomalies within spring $(-4 \mathrm{hPa})$ and summer WS days ( $-2 \mathrm{hPa}$ ) (Fig. 7).

The WS intra annual variability of synoptic conditions (not shown) is discussed further below. The daily composite mean of geopotential heights at $500 \mathrm{hPa}$ level during December WS days reveals a SW air flow over western Greece as a long trough is highlighted along the central the Adriatic Sea and southern parts of Italy. During January and February WS days, the trough line over central Italy maintains the SW upper air flow stream over western Greece. From March to April the upper air stream at $500 \mathrm{hPa}$ level is slightly shifted to westerly flow, as the trough is located over the Balkans, against a closed cyclonic circulation over Albania during May WS days. Within June and July WS days, the daily composite mean of geopotential heights at $500 \mathrm{hPa}$ level presents a long trough along eastern parts of Europe and southern parts of Italy. The zonal upper air flow within August WS days is shifted towards SW directions during September, October and November, as the trough is established eastwards over Italy. Taking into consideration the surface synoptic conditions, the daily composite mean of SLP, during December to March WS days, depicts a closed cyclonic circulation over the Gulf of Taranto, with the lower value of $1004 \mathrm{hPa}$ in February. The combination of high pressure system over central Europe with low pressure system over the eastern Mediterranean Sea implies a shallow cyclonic circulation over the Ionian Sea during April, June, July and August. During October and November a closed cyclonic circulation is located over the Gulf of Taranto and central parts of Italy, suggesting a SW surface airflow.

\subsection{Seasonal composite anomalies of synoptic conditions and lifted index for tornadic events over western Greece}

The performed analysis demonstrated that tornadoes are more frequent over western Greece during autumn. The daily composite mean of geopotential heights at $500 \mathrm{hPa}$ isobaric level reveals a trough line across the northern Adriatic Sea and central Italy, associated with a SW upper-air stream over western Greece. During autumn, the maximum daily composite anomaly of geopotential heights at $500 \mathrm{hPa}$ isobaric 
level appears over central parts of Italy. SW surface air stream is the main characteristic of daily composite mean of synoptic conditions for TR days within autumn and winter season, as the centre of low pressure system is identified near the Gulf of Taranto. November favours mostly the development of tornadoes, followed by October. During November TR days, a long wave trough line at $500 \mathrm{hPa}$ level is oriented from NE Italy to the north coasts of Africa. This trough line is also distinguished at $700 \mathrm{hPa}$ level, compared to lower isobaric levels ( 850 and $925 \mathrm{hPa}$ ), where a closed cyclonic circulation appears over central Italy. Besides, at SLP, a low pressure centre is identified over central Italy with a mean pressure of $1004 \mathrm{hPa}$.

The southwestern upper air stream at $500 \mathrm{hPa}$ isobaric level accompanied with a long wave along central and southern Italy are the common characteristics of the prevailed synoptic patterns during autumn, that provide favourable condition for the development of tornadoes and waterspouts. The daily composite anomaly at $500 \mathrm{hPa}$ isobaric level in autumn is maximum against to that of winter. Furthermore, the closed cyclonic circulation depicted from the daily composite anomaly of SLP over the Gulf of Taranto during tornado days is deeper compared to waterspout days. During the spring season the daily composite anomaly at $500 \mathrm{hPa}$ isobaric level, during tornado days, is characterized by a closed cyclonic circulation against a long wave trough located along the Ionian Sea, for waterspout days.

Figure 9 (left column) depicts the TR seasonal box and whisker plots of daily anomalies of the geopotential heights at isobaric levels of 500, 700, 850 and $925 \mathrm{hPa}$, calculated at the location of each event in western Greece, from $12 \mathrm{Au}-$ gust 1953 to 31 December 2012. The maximum of daily anomalies of the geopotential heights (m) appears in autumn season at the isobaric level of $500 \mathrm{hPa}$. During autumn, the median of the daily anomalies of the geopotential heights at isobaric levels of 500, 700, 850 and $925 \mathrm{hPa}$ ranges from -65 to $-55 \mathrm{~m}$. Higher anomalies (high negative median) of the geopotential heights at $500 \mathrm{hPa}$ level have been identified for spring and summer against winter when the higher anomalies (high negative median) of the geopotential heights appear at the lowest isobaric level of $925 \mathrm{hPa}$. Compared to tornadoes, waterspouts reveal similar box and whisker plots of daily anomalies of geopotential heights at the aforementioned isobaric levels (Fig. 9, right column), during spring, summer and autumn (high negative median at upper levels, low negative median at lower levels). An opposite pattern is identified during winter, when the higher anomalies (high negative median) of geopotential heights appear at $500 \mathrm{hPa}$.

The seasonal box and whisker plots of the daily anomalies of SLP (hPa) for TR and WS days (calculated at the location of the event) are depicted in Fig. 10 (upper graphs). The maximum the daily anomalies (hPa) for TR days appear during winter, followed by autumn, spring and summer (Fig. 10). The intra-annual variability of SLP daily anomalies (not shown) over western Greece shows the highest me-
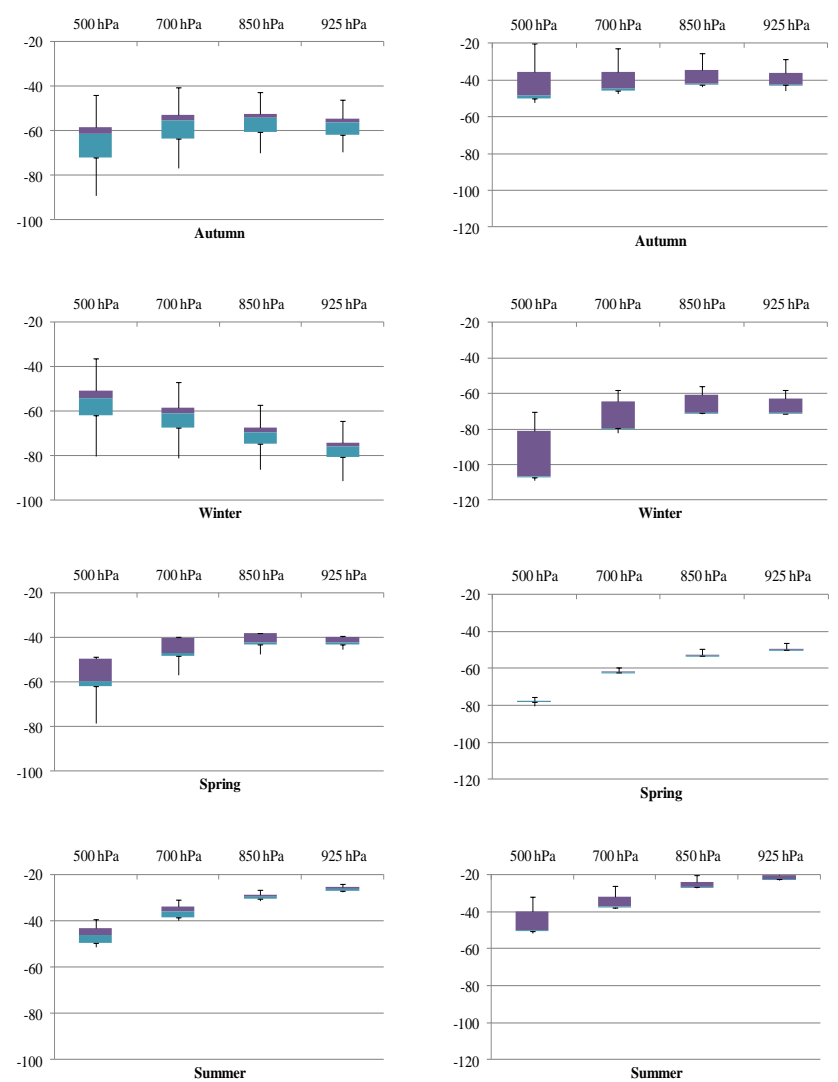

Figure 9. Box and whisker plots of seasonal daily anomalies of the geopotential heights (m) at isobaric levels of 500, 700, 850 and $925 \mathrm{hPa}$, for tornadoes (left column) and waterspouts (right column), calculated at the location of each event in western Greece, from 12 August 1953 to 31 December 2012. The horizontal line in the box represents the median, the box represents the 25 th and 75 th percentile and the whiskers refer to maximum and minimum daily anomalies.

dian values of $-21 \mathrm{hPa}$ during January, $-12 \mathrm{hPa}$ during May and $-10 \mathrm{hPa}$ during November. Similar findings have been found with respect to the seasonal box and whisker plots of the daily anomalies of SLP (hPa) for WS days (Fig. 10).

The monthly variability of the dynamic lifted index (LI) for TR days is also examined based on NCEP-NCAR reanalysis data sets. Box and whisker plots of the daily means and anomalies of LI for TR days over western Greece are depicted in Fig. 10 (lower graphs). The median of the daily means of LI (box and whisker plots) remains below -1 from June to November and thereafter slightly changes with values near to 0 from December to March (Fig. 10, lower left graph). As far as the box and whisker plots of the daily anomalies of LI are concerned, the median presents the highest negative value in January followed by December, November and October (Fig. 10, lower right graph).

Apart from the analysis of the daily means and anomalies of LI and synoptic conditions at specific isobaric levels, along western Greece, the authors investigated the 

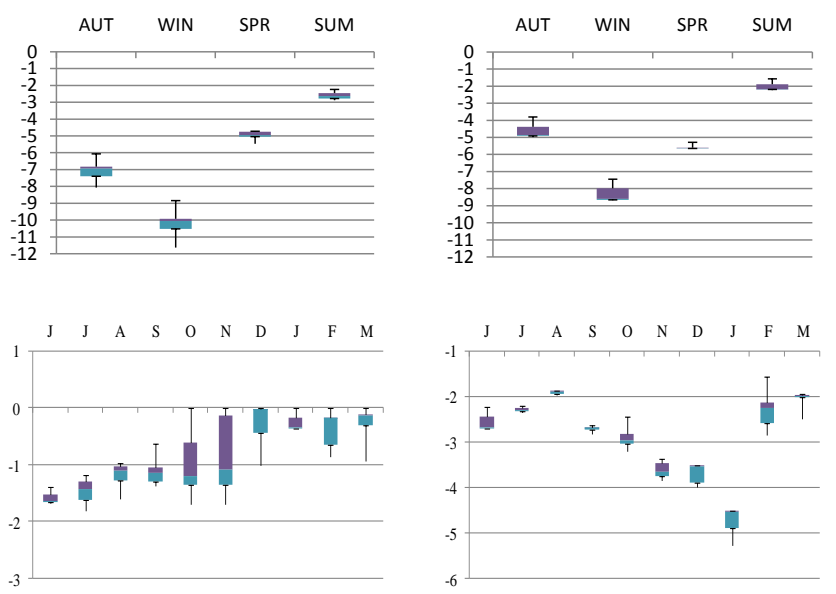

Figure 10. Box and whisker plots of seasonal daily anomalies of the sea level pressure (hPa) for tornadoes (upper left graph) and waterspouts (upper right graph) calculated at the location of each event in western Greece, from 12 August 1953-31 December 2012. Lower graphs depict box and whisker plots of monthly (June to March) daily means (lower left graph) and anomalies (lower right) of lifted index (LI), based on NCEP-NCAR reanalysis data sets during tornado days over western Greece for the period 12 August 195331 December 2012. The horizontal line in the box represents the median, the box represents the 25 th and 75 th percentile and the whiskers refer to maximum and minimum daily anomalies.

association of tornado occurrence to frontal waves during the most favourable season (autumn). The association of tornadoes to frontal waves has been considered in recent studies (Clark, 2008; Smart and Browning, 2009; Groenemeijer et al., 2010). Markowski et al. (1998) found that nearly $70 \%$ of tornadoes during the Verification of the Origins of Rotation in Tornadoes EXperiment (VORTEX) occurred near a pre-existing baroclinic boundary, most of them within $30 \mathrm{~km}$ distance on its cold side.

All examined frontal waves along the Ionian Sea, during autumn TR events from 2006 to 2012, based on UK Met Office analysis, have been digitized using Geographical Information System (GIS, ArcGiS). Based on this analysis, the $48 \%$ of autumn TR events occur in pre-frontal weather conditions (cold fronts) and $27 \%$ appear after the passage of the cold front. Figure 11 illustrates the digitized cold fronts from UK Met Office analysis, as well as TR damage along western Greece, indicating the great impact on the local society, as numerous damage to crops and structures have been recorded (Fig. 11).

\section{Conclusions}

The purpose of this work was to analyze in terms of seasonal the daily composite means and anomalies of synoptic conditions favour for tornado and waterspout development over western Greece from 1953 to 2012. The performed analy-

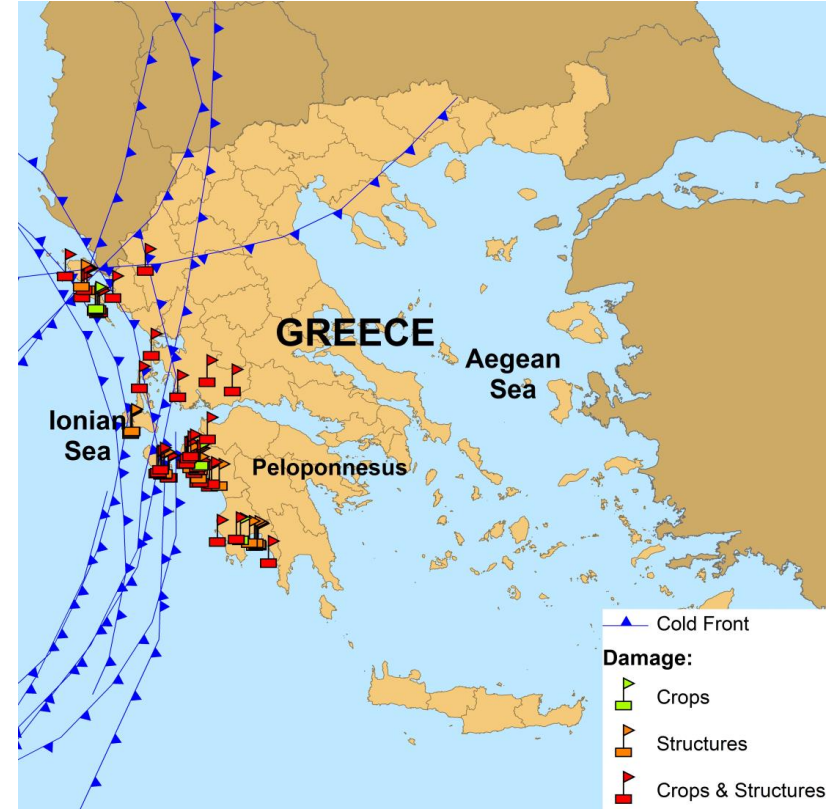

Figure 11. Cold front activity associated with pre-frontal tornado occurrence during autumn from 2006 to 2012. Flag symbols correspond to impacts on crops (green flag), structures (orange flag) and crops with structures (red flag) during tornado days over western Greece the period 12 August 1953-31 December 2012.

ses resulted that tornadoes are more frequent over western Greece during autumn.

According to the performed analysis, the main findings are the following:

- The daily composite mean of geopotential heights at $500 \mathrm{hPa}$ isobaric level revealed a trough line across the northern Adriatic Sea and central Italy, associated with a SW upper-air stream over western Greece.

- SW surface air stream is the main characteristic of daily composite mean of synoptic conditions for TR days within the autumn and winter seasons, as the centre of low pressure system is identified near the Gulf of Taranto.

- The common synoptic characteristic of synoptic pattern between tornado and waterspout days along western Greece during autumn are the SW upper air stream at $500 \mathrm{hPa}$ and a long wave trough along southern Italy.

- The main difference concerning synoptic pattern between tornado and waterspout days along western Greece during autumn is the maximum daily composite anomaly over the Gulf of Taranto.

- Tornado days revealed that the maximum of daily composite anomalies of the geopotential heights (m) occurred during autumn, spring and summer at the isobaric level of $500 \mathrm{hPa}$, in contrast to winter season when 
the maximum anomaly was illustrated at the isobaric level of $925 \mathrm{hPa}$.

- During waterspout days the maximum daily composite anomaly during all seasons was depicted at the isobaric level of $500 \mathrm{hPa}$.

- The maximum daily anomalies for TR and WS days appeared during winter, followed by autumn. Similarly, the maximum daily anomaly of LI was illustrated during cold season.

- $48 \%$ of TR events during autumn occurred in prefrontal weather conditions (cold fronts) and $27 \%$ appeared after the passage of the cold front.

Regarding our future work, it is planned to extend the present research to further investigation of synoptic types that associated with tornadogenesis. Concerning this direction, Matsangouras et al. (2013) suggested a seasonal objective synoptic classification for western Greece (D10) per tornadic type, and recognized specific synoptic weather patterns favourable for tornado and waterspout occurrence.

Acknowledgements. The authors thank the Hellenic National Meteorological Service (HNMS), Hellenic National Library, Aristotle University of Thessaloniki (Psifiothiki), state authorities, media (blogs, news site, TV and radio stations), who contribute to accomplish tornadic database. Authors acknowledge UK Met Office. Daily composite images were provided by the NOAA/ESRL Physical Sciences Division, Boulder Colorado.

Edited by: N. R. Dalezios

Reviewed by: two anonymous referees

\section{References}

Bertato, M., Giaiotti, D. B., Manzato, A., and Stel, F.: An interesting case of tornado in Friuli-North-eastern Italy, Atmos. Res., 67-68, 3-21, 2003.

Brázdil, R., Chromá, K., Dobrovolný, P., and Černoch, Z.: The tornado history of the Czech Lands, AD 1119-2010, Atmos. Res. 118, 193-204, 2012.

Clark, M. R.: The southern England tornadoes of 30 December 2006:case study of a tornadic storm in a low SBCAPE, high shear environment, Atmos. Res. 93, 50-65, 2008.

Dessens, J.: Les Trombes en France. Climatologie et Caractéristiques Physiques, Lannemezan, France, 1984.

Dessens, J. and Snow, J. T.: Tornadoes in France, Weather Forecast., 4, 110-132, 1987.

Dotzek, N.: Tornadoes in Germany, Atmos. Res., 56, 233-251, 2001.

Dotzek, N.: An updated estimate of tornado occurrence in Europe, Atmos. Res., 67-68, 153-161, 2003.

Fiedler, B. H.: Suction vortices and spiral breakdown in numerical simulations of tornado-like vortices, Atomos. Sci. Lett., 10, 109$114,2009$.
Fiedler, B. H. and Rotunno, R.: A theory for the maximum windspeeds in tornado-like vortices, J. Atmos. Sci., 43, 2328-2340, 1986.

Fujita, T. T.: Tornadoes around the world, Weatherwise, 26, 56-83, 1973.

Gayà, M., Homar, V., Romero, R., and Ramis, C.: Tornadoes and waterspouts in the Balearic Islands: Phenomena and environment characterization, Atmos. Res., 56, 253-267, 2000.

Gayà, M., Llasat, M.-C., and Arús, J.: Tornadoes and waterspouts in Catalonia (1950-2009), Nat. Hazards Earth Syst. Sci., 11, 18751883, doi:10.5194/nhess-11-1875-2011, 2011.

Giaiotti, D. B., Giovannoni, M., Pucillo, A., and Stel, F.: The climatology of tornadoes and waterspouts in Italy, Atmos. Res., 83, 534-541, 2007.

Gianfreda, F., Miglietta, M. M., and Sansò, P.: Tornadoes in Southern Apulia (Italy), Nat. Hazards, 34, 71-89, 2005.

Golden, J. H.: Some statistical aspects of waterspout formation, Weatherwise, 26, 108-117, 1973.

Golden, J.: The life-cycle of Florida Keys' waterspouts I, J. Appl. Meteor., 13, 676-692, 1974a.

Golden, J.: Scale-interaction implications for the waterspout life cycle II, J. Appl. Meteor., 13, 693-709, 1974b.

Golden, J.: An assessment of waterspout frequencies along the U.S. East and Gulf Coasts, J. Appl. Meteorol., 16, 231-236, 1977.

Grazulis, T. P.: Significant Tornadoes, 1680-1991, Environmental Films, St. Johnsbury, VT, 1326 pp., 1993.

Groenemeijer, P., Corsmeier, U., and Kottmeier, Ch.: The development of tornadic storms on the cold side of a front favoured by local enhancement of moisture and CAPE, Atmos. Res., 83, 765781, 2010.

Holzer, A. M.: Tornado climatology of Austria, Atmos. Res., 56, 203-211, 2001.

Howells, P. A., Rotunno, R., and Smith, R. K.: A comparative study of atmospheric and laboratory-analogue numerical tornado-vortex models, Q. J. Roy. Meteorol. Soc., 114, 801-822, 1988.

Kalnay, E., Kanamitsu, M., Kistler, R., Collins, W., Deaven, D., Gandin, L., Iredell, M., Saha, S., White, G., Woollen, J., Zhu, Y., Chelliah, M., Ebisuzaki, W., Higgins, W., Janowiak, J., Mo, K. C., Ropelewski, C., Wang, J., Leetmaa, A., Reynolds, R., Jenne, R., and Joseph, D.:The NCEP/NCAR Reanalysis 40-year Project, B. Am. Meteorol. Soc., 77, 437-471, 1996.

Keul, A. G., Sioutas, M. V., and Szilagyi, W.: Prognosis of centraleastern Mediterranean waterspouts, Atmos. Res., 93, 426-436, 2009.

Klemp, J. B.: Dynamics of tornadic thunderstorms, Annu. Rev. Fluid Mech., 19, 369-402, 1987.

Marcinoniene, I.: Tornadoes in Lithuania in the period of 1950-2002 including analysis of the strongest tornado of 29 may 1981, Atmos. Res., 67-68, 475-484, 2003.

Markowski, P. M., Rasmussen, E. N., and Straka, J. M.: The occurrence of tornadoes in supercells interacting with boundaries during VORTEX-95, Weather Forecast., 13, 852-859, 1998.

Matsangouras, I. T. and Nastos, P. T.: The 27 July 2002 tornado event in Athens, Greece, Adv. Sci. Res., 4, 9-13, 2010.

Matsangouras, I. T., Nastos, P. T., and Nikolakis, D.: Study of meteorological conditions related to the tornado activity on 253-2009 over NW Peloponnesus, Greece, in: Proc. 10th International Conference on Meteorology, Climatology and Atmo- 
spheric Physics (COMECAP2010), 25-38 May 2010, Patras, Greece, 417-425, 2010 (in Greek).

Matsangouras, I. T., Nastos, P. T., and Sioutas, M. V.: 300 Years historical records of tornadoes, waterspouts and funnel clouds over Greece, 6th European Conference on Severe Storms (ECSS 2011), 3-7 October 2011, Palma de Mallorca, Balearic Islands, Spain, 2011a.

Matsangouras, I. T., Nastos, P. T., and Pytharoulis, I.: Synopticmesoscale analysis and numerical modeling of a tornado event on 12 February 2010 in northern Greece, Adv. Sci. Res., 6, 187194, $2011 b$.

Matsangouras, I. T., Nastos, P. T., and Pytharoulis, I.: Numerical Investigation of the Role of Topography in Tornado Events in Greece, in: Advances in Meteorology, Climatology and Atmospheric Physics, edited by: Helmis, C. G. and Nastos, P. T., Springer Berlin Heidelberg, doi:10.1007/978-3-642-291722_30, 209-215, 2012.

Matsangouras, I. T., Nastos, P. T., Smith, R., Blair, D., and Dahni, R.: An objective synoptic classification of tornadic days over Greece, in: 13th Annual Meeting of the European Meteorological Society (EMS) and the 11th European Conference on Applied Climatology (ECAC), 2013.

Matsangouras, I. T., Nastos, P. T., Bluestein, H. B., and Sioutas, M. V.: A climatology of tornadic activity over Greece based on historical records, Int. J. Climatol., 34, 2538-2555, doi:10.1002/joc.3857, 2014.

Meaden, G. T.: Tornadoes in Britain: Their intensities and distribution in space and time, J. Meteorol., 1, 242-251, 1976.

Miller, R. C.: Notes on analysis and severe-storm forecasting procedures of the Air Force Global Weather Central. AWS Tech. Rep. 200 (rev.), Air Weather Service, Scott AFB, IL, 190 pp., 1972.

Nastos, P. T. and Matsangouras, J. T.: Tornado activity in Greece within the 20th century, Adv. Geosci., 26, 49-51, doi:10.5194/adgeo-26-49-2010, 2010.

Nastos, P. T. and Matsangouras, I. T.: Composite Mean and Anomaly of Synoptic Conditions for Tornadic Days over North Ionian Sea (NW Greece), in: Advances in Meteorology, Climatology and Atmospheric Physics, edited by: Helmis, C. G. and Nastos, P. T., Springer Berlin Heidelberg, doi:10.1007/978-3642-29172-2_91, 639-645, 2012.

Nastos, P. T., Matsangouras, I. T., and Chronis, T. G.: Spatiotemporal analysis of lightning activity over Greece - Preliminary results derived from the recent state precision lightning network, Atmos. Res., 144, 207-217, 2014.

Paul, J. F.: An inventory of tornadoes in France, Weather, 54, $217-$ 219, 1999

Peterson, R. E.: Tornadic activity in Europe - The last half-century, Paper presented at the Conference on Severe Local Storms, 6366, 1982.

Peterson, R. E.: Letzmann and Koschmieder's "Guidelines for research on funnels, tornadoes, waterspouts and whirlwinds", B. Am. Meteorol. Soc., 73, 597-611, 1992.

Peterson, R. E.: Johannes Peter Letzmann: Pioneer tornado researcher, in: Meteorology in Estonia in Johannes Letzmann's Times and Today, edited by: Eelsalu, H. and Tooming, H., Estonian Academy Publishers, 9-43, 1995.
Peterson, R. E.: A historical review of tornadoes in Italy, J. Wind Eng. Ind. Aerodyn., 74-76, 123-130, 1998.

Rauhala, J. and Schultz, D. M.: Synoptic climatology of tornadoes in Finland. 5th European Conference on Severe Storms (ECSS 2009), 12-16 October 2009, Landshut, Germany, 2009.

Rauhala, J., Brooks, E. H., and Schultz, M. D.: Tornado climatology of Finland, Mon. Weather Rev., 140, 1446-1456, 2012.

Reynolds, D. J.: A revised U.K. tornado climatology, 1960-1989, J. Meteorol., 24, 290-321, 1999a.

Reynolds, D. J.: European tornado climatology 1960-1989, J. Meteorol., 24, 376-403, 1999b.

Rotunno, R.: Numerical simulation of a laboratory vortex, J. Atmos. Sci., 34, 1942-1956, 1977.

Rotunno, R.: A note on the stability of a cylindrical vortex sheet, J. Fluid Mech., 87, 761-771, 1978.

Rotunno, R.: A study in tornado-like vortex dynamics, J. Atmos. Sci., 36, 140-155, 1979.

Rotunno, R.: Vorticity dynamics of a convective swirling boundary layer, J. Fluid Mech., 97, 623-640, 1980.

Rotunno, R.: An investigation of a three-dimensional asymmetric vortex, J. Atmos. Sci., 41, 283-298, 1984.

Rotunno, R.: The Fluid Dynamics of Tornadoes, Ann. Rev. Fluid Mechan., 45, 59-84, 2013.

Setvák, M., Šálek, M., and Munzar, J.: Tornadoes within the Czech Republic: From early medieval chronicles to the "internet society", Atmos. Res., 67-68, 589-605, 2003.

Sioutas, M. V.: Tornadoes and waterspouts in Greece, Atmos. Res., 67-68, 645-656, 2003

Sioutas, M. V.: A tornado and waterspout climatology for Greece, Atmos. Res., 100, 344-356, 2011.

Sioutas, M. V. and Keul, A. G.: Waterspouts of the Adriatic, Ionian and Aegean Sea and their meteorological environment, Atmos. Res., 83, 542-557, 2007.

Smart, D. J. and Browning, K. A.: Morphology and evolution of cold-frontal misocyclones, Q. J. Roy. Meteorol. Soc., 639, 381393, 2009.

Tarand, A.: How often do tornadoes occur in Estonia? Meteorology in Estonia, in: Johannes Letzmann's Times and Today, edited by: Eelsalu, H. and Tooming, H., Estonian Academy Publishers, 132-138, 1995.

Tooming, H. K. and Peterson, R. E.: Vigorous tornadoes and waterspouts during the last 35 years in Estonia. Meteorology in Estonia in: Johannes Letzmann's Times and Today, edited by: Eelsalu, H. and Tooming, H., Estonian Academy Publishers, 168-179, 1995.

Tyrrell, J.: Tornadoes in Ireland: an historical and empirical approach, Atmos. Res., 56, 281-290, 2001.

Wegener, A.: Wind-und Wasserhosen in Europa, Vieweg. Braunschweig, 301 pp., 1917.

Wilson, T. and Rotunno, R.: Numerical simulation of a laminar endwall vortex and boundary layer, Phys. Fluids, 29, 3993-4005, 1986. 